\title{
CALLUS FORMATION, PHENOLICS CONTENT AND RELATED ANTIOXIDANT ACTIVITIES IN TISSUE CULTURE OF A MEDICINAL PLANT COLOCYNTH (Citrullus colocynthis)
}

\author{
FAROUK K. EL-BAZ, AMAL A. MOHAMED, SAMI I. ALI \\ Plant Biochemistry Department, National Research Centre, Dokki, Cairo, Egypt \\ (amin_amal@yahoo.com)
}

\begin{abstract}
Callus cultures from stems, leaves and roots of colocynth were initiated on MS media supplemented with various combinations of 2,4 dichlorophenoxyacetic acid (2,4-D) with kinetin (KIN) and benzyladenine (BA) with $\alpha$-naphthaleneacetic acid (NAA). The highest percentage of callus formation frequency $(98.9 \%)$ was obtained from stem explants grown on MS media supplemented with $(1.0 \mathrm{mg} / \mathrm{L})$ $2,4-\mathrm{D}+(1.0 \mathrm{mg} / \mathrm{L}) \mathrm{KIN}$. The total phenolics and flavonoid content of the colocynth callus cultures were measured. The results showed that the MS medium supplemented with $6.0 \mathrm{mg} / \mathrm{L} 2,4-\mathrm{D}+2.0 \mathrm{mg} / \mathrm{L} \mathrm{KIN}$ (MD3) gave the highest content of total phenolics $(19.2 \mathrm{mg} / 100 \mathrm{~g}$ d.w.) in leaf-derived calli. The highest content of flavonoids $(47.3 \mathrm{mg} / 100 \mathrm{~g}$ d.w.) was obtained in stem derived calli grown on the same medium (MD3). Antioxidant activities of extracts were determined using different assays, including DPPH radical scavenging activity, hydrogen peroxide $\left(\mathrm{H}_{2} \mathrm{O}_{2}\right)$ scavenging activity and ferric reducing power. Leaf-derived calli cultured on MS medium + 2.0 mg/L 2,4-D + $1.0 \mathrm{mg} / \mathrm{L} \mathrm{KIN} \mathrm{(MD1)} \mathrm{showed} \mathrm{the} \mathrm{highest} \mathrm{DPPH} \mathrm{radical}$ scavenging activity $(85.3 \%)$. The highest percentage of $\mathrm{H}_{2} \mathrm{O}_{2}$ scavenging activity $(61.4 \%)$ was detected in leaf explant-derived calli growing on MD1. The leaf-derived calli growing on (MD3) gave the highest ferric reducing power $(22.3 \mu \mathrm{g} / \mathrm{g}$ d.w.), compared to the activities of stems, leaves and roots of in vitro grown seedlings $(3.28,12.9$ and $2.85 \mu \mathrm{g} / \mathrm{g}$ d.w.), which were used as controls. On the basis of the current findings, we conclude that MS media supplemented with different combinations of 2,4-D and KIN yields higher phenolics, flavonoids contents and antioxidant activities than MS media supplemented with BA and NAA.
\end{abstract}

Key words: callus culture, phenolics, flavonoids, $\mathrm{H}_{2} \mathrm{O}_{2}$ scavenging activity, plant growth regulators

\section{Introduction}

Plant cell cultures are an attractive alternative source to whole plant for the production of high value secondary metabolites (ALFERMANN and PETERSEN, 1995; DORNENBURG and KNORR, 1997). However, a considerable progress has been made to stimulate production and accumulation of secondary metabolites using plant cell cultures (KALIDASS et al., 2010; ABOUZID et al., 2010).

Several strategies have been adopted for the enhancement of bioactive metabolite production in in vitro cultures; one of them is using growth regulators which are often a crucial factor in secondary product accumulation (DUANGPORN and SIRIPONG, 2009). The type and concentration of auxin or cytokinin or the auxin/cytokinin ratio may alter dramatically both the growth and the product formation in cultured plant cells (MANTELL and SMITH, 1984). Auxin appears to be the primary factor controlling growth and morphology of roots, while the effects of cytokinin vary depending on secondary metabolites and species concerned (ROA and RAVISHANKAR, 2002). For example kinetin stimulated the production of anthocyanins in Haplopappus gracilus but inhibited the formation of anthocyanins in Populus cell cultures (SEITZ and HINDERER, 1988). 
In recent years, with enhanced awareness of the importance of antioxidant compounds in health and disease, considerable attention has been devoted to medicinal plants with high antioxidant properties (KONG et al., 2010; MOHAMED et al., 2010). Colocynth or bitter melon (Citrullus colocynthis) is a medicinal plant species of Cucurbitaceae family. It grows fast in sandy soils and is widespread in different parts of South Eastern Desert of Egypt (HASSANANE et al., 2001). A number of secondary metabolites have previously been reported in this plant including cucurbitacins, flavonoids, caffeic acid derivatives and terpenoids in addition to flavonoid glycosides and cucurbitacin glucosides (SEGER et al., 2005; DELAZAR et al., 2006). Moreover, higher content of total cucurbitacins and cucurbitacin-E have been attained in colocynth callus culture as a result of the impact of different combinations of growth regulators (HEGAZY et al., 2010). Colocynth fruit extracts demonstrated activity against some bacteria and fungi prevalent in dermatology, so it can be considered as an effective antimicrobial agent to treat numerous diseases (ZIYYAT et al., 1997). No information is available about the stimulation effects of plant growth regulators on antioxidant activity of colocynth callus cultures. The aim of this study was to develop conditions for callus cultures of $C$. colocynthis manipulating the concentrations and combinations of plant growth regulators, and determination of the effect of media composition on total phenolics and flavonoids content together with the related antioxidant activity of induced calli.

\section{Materials and methods}

\subsection{Plant material}

Mature seeds of $C$. colocynthis (L.) Schrad. were collected from naturally growing plant populations in Wadi Soule, Sinai, Egypt. The collected seed material was botanically authenticated by the Herbarium of the Botany Dept., Faculty of Science, Cairo University. Dehusked sterilized seeds were in vitro germinated on hormone-free MS medium (MURASHIGE and SKOOG, 1962).

\subsection{In vitro culture and growth regulators treatments}

Two weeks old in vitro germinated seedlings of $C$. colocynthis were used as a source of explants for initiation of callus cultures. Stems, leaves and roots were cut into small pieces and cultured on MS medium supplemented with different combinations of 2,4-dichlorophenoxyacetic acid (2,4-D) and Kinetin (KIN) as well as BA and NAA in different concentrations as presented in Table 1. The cultures were incubated for callus induction in the growth chamber at $24 \pm 2^{\circ} \mathrm{C}$ under a fluorescent light $\left(80 \mu \mathrm{E} \mathrm{m}^{-2} \mathrm{~s}^{-1}\right)$ at a 16 -h photoperiod for three weeks. After that callus samples were collected for determination of callusing frequency as well as determination of total phenolics, total flavonoid and antioxidant activity by different methods.

\subsection{Callusing frequency}

The frequency of callus induction was calculated according to the following formula: Callus induction frequency $(\%)=[$ No. of seeds produced calli / No. of seeds cultured] x 100 . 
Table 1. List of MS media supplemented with different growth regulators used for colocynth callus cultures.

\begin{tabular}{ccc}
\hline No. & Media codes & Growth regulators concentration $(\mathrm{mg} / \mathrm{L})$ \\
\hline 1 & MD1 & MS $+2.02,4-\mathrm{D}+1.0 \mathrm{KIN}$ \\
2 & $\mathrm{MD} 2$ & $\mathrm{MS}+1.02,4-\mathrm{D}+1.0 \mathrm{KIN}$ \\
3 & $\mathrm{MD} 3$ & $\mathrm{MS}+6.02,4-\mathrm{D}+2.0 \mathrm{KIN}$ \\
4 & $\mathrm{MD} 4$ & $\mathrm{MS}+2.02,4-\mathrm{D}+4.0 \mathrm{KIN}$ \\
\hline 5 & $\mathrm{MB} 1$ & $\mathrm{MS}+0.0 \mathrm{BA}+5.0 \mathrm{NAA}$ \\
6 & $\mathrm{MB} 2$ & $\mathrm{MS}+0.01 \mathrm{BA}+1.0 \mathrm{NAA}$ \\
7 & $\mathrm{MB} 3$ & $\mathrm{MS}+0.1 \mathrm{BA}+5.0 \mathrm{NAA}$ \\
8 & $\mathrm{MB} 4$ & $\mathrm{MS}+1.0 \mathrm{BA}+0.1 \mathrm{NAA}$ \\
\hline
\end{tabular}

\subsection{Preparation of plant extracts}

Callus cultures derived from stems, leaves and roots as well as in vitro raised seedling materials (used as control) were air dried at room temperature and ground in a mortar. The extracts were prepared using the modified method of MATKOWSKI and PIOTROWSKA (2006). Briefly, $0.5 \mathrm{~g}$ of the dried powder from each sample was refluxed with methanol in a water bath at $45^{\circ} \mathrm{C}$ for $3 \mathrm{~h}$. The extracts were filtered through Whatman filter paper No. 4. The collected filtrates were dried under vacuum at $40^{\circ} \mathrm{C}$. The extraction was repeated twice. The resulting residue was re-dissolved in methanol and used for the determination of phenolics, flavonoid contents and antioxidant activities.

\subsection{Determination of total phenolics content}

The total phenolics content of the extracts was determined using the FolinCiocalteu reagent (KAUR and KAPOOR, 2002). Each extract solution $(200 \mu \mathrm{L})$ was completed to $3 \mathrm{~mL}$ with distilled water then mixed thoroughly with $0.5 \mathrm{~mL}$ of FolinCiocalteu reagent. After mixing for $3 \mathrm{~min}, 2 \mathrm{~mL}$ of $20 \%$ (w/v) sodium carbonate was added and allowed to stand for a further $60 \mathrm{~min}$ in the dark. The absorbance of the reaction mixtures were measured at $650 \mathrm{~nm}$. The total phenolics content was expressed as mg pyrogallol equivalents / $100 \mathrm{~g}$ dry weight (d.w.) of the extract.

\subsection{Determination of total flavonoid content}

The total flavonoid content was determined according to the method of KIM et al. (2003). In brief, $0.5 \mathrm{~mL}$ of sample solution was completed to $1 \mathrm{~mL}$ with methanol then mixed with $4 \mathrm{~mL}$ of distilled water and subsequently with $0.3 \mathrm{~mL}$ of $5 \% \mathrm{NaNO}_{2}$ solution. After $6 \mathrm{~min}$ of incubation, $0.3 \mathrm{~mL}$ of $10 \% \mathrm{AlCl}_{3}$ solution was added and then allowed to stand for $5 \mathrm{~min}$, followed by adding $2 \mathrm{~mL}$ of $1 \mathrm{M} \mathrm{NaOH}$ solution to the mixture. Immediately after water was added to the sample to bring the final volume to $10 \mathrm{~mL}$ and the mixture was thoroughly mixed. The absorbance was determined at 510 $\mathrm{nm}$. The total flavonoid content was expressed as $\mathrm{mg}$ rutin equivalents / $100 \mathrm{~g}$ d.w. of the extract. 


\subsection{Determination of antioxidant activity}

\subsubsection{DPPH free radical scavenging activity}

Quantitative measurement of radical scavenging properties of colocynth was carried out according to the method of BLOIS (1958). Briefly, $0.1 \mathrm{mM}$ solution of 1,1diphenyl-2-picryl-hydrazyl (DPPH.) in methanol was prepared and $1 \mathrm{~mL}$ of this solution was added to $3 \mathrm{~mL}$ of each methanolic extract at one concentration (500 $\mu \mathrm{g} / \mathrm{mL}$ ). Butylated hydroxytoluene (BHT) was used as a positive control. Discoloration was measured at $517 \mathrm{~nm}$ after incubation for $30 \mathrm{~min}$. Measurements were taken at least in triplicate. The capacity to scavenge the DPPH radical was calculated using the following equation:

$$
\text { DPPH. scavenging effect }(\%)=\left[\mathrm{A}_{D P P H}-\mathrm{A}_{S} / \mathrm{A}_{D P P H}\right] \times 100
$$

where, $\mathrm{A}_{D P P H}$ is the absorbance of the DPPH. solution and $\mathrm{A}_{S}$ is the absorbance of the solution when the sample extract is added. The extract concentration providing $50 \%$ inhibition of radical-scavenging activity $\left(\mathrm{IC}_{50}\right)$ was calculated and expressed as $\mathrm{mg} / \mathrm{mL}$, d.w.

\subsubsection{Ferric reducing power determination}

Ferric reducing power was determined following the method reported by ZHAO et al. (2008). Extracts at concentration of $500 \mu \mathrm{g} / \mathrm{mL}$ were mixed with phosphate buffer $(2.5 \mathrm{~mL}, 200 \mathrm{mM}, \mathrm{pH} 6.6)$ and $1 \%$ potassium ferricyanide $(2.5 \mathrm{~mL})$. Then the mixtures were incubated at $50{ }^{\circ} \mathrm{C}$ for $20 \mathrm{~min}$. The quantity $2.5 \mathrm{~mL}$ of $10 \%$ trichloroacetic acid was added and the mixture was centrifuged at $10000 \mathrm{rpm}$ for $10 \mathrm{~min}$. The upper layer of the solution $(5 \mathrm{~mL})$ was mixed with distilled water $(5 \mathrm{~mL})$ and $0.1 \%$ ferric chloride $(1 \mathrm{~mL})$. The absorbance of the reaction mixtures were measured at $700 \mathrm{~nm}$. The final results were expressed as $\mu \mathrm{g}$ ascorbic acid equivalents / $\mathrm{g}$ based on dry weight of the extract.

\subsubsection{Hydrogen peroxide scavenging activity}

The hydrogen peroxide scavenging ability of methanolic extracts was determined according to the method of SHON et al. (2007). A solution of $\mathrm{H}_{2} \mathrm{O}_{2}$ (43 $\mathrm{mM})$ was prepared in phosphate buffer $(0.1 \mathrm{M}, \mathrm{pH}$ 7.4). Extracts at concentration $50 \mu \mathrm{g} / \mathrm{mL}$ dissolved in $3.4 \mathrm{~mL}$ phosphate buffer were added to a $\mathrm{H}_{2} \mathrm{O}_{2}$ solution $(600 \mu \mathrm{L})$. The absorbance of the reaction mixture was recorded at $230 \mathrm{~nm}$. The percentage of $\mathrm{H}_{2} \mathrm{O}_{2}$ scavenging of each extract and BHT at concentration $50 \mu \mathrm{g} / \mathrm{mL}$ used as positive control was calculated as:

$$
\mathrm{H}_{2} \mathrm{O}_{2} \text { scavenging effect }(\%)=\left[\mathrm{A}_{\text {Control }}-\mathrm{A}_{\text {Sample }} / \mathrm{A}_{\text {Control }}\right] \times 100
$$

where $\mathrm{A}_{\text {Control }}$ is the absorbance of the control (blank, without extract), and $\mathrm{A}_{\text {Sample }}$ is the absorbance in the presence of the sample extract. 
The extract concentration providing $50 \%$ of $\mathrm{H}_{2} \mathrm{O}_{2}$ scavenging activity $\left(\mathrm{IC}_{50}\right)$ was calculated and expressed as $\mu \mathrm{g} / \mathrm{mL}$ based on sample dry weight.

\subsection{Statistical analysis}

The experiment was conducted using Completely Randomized Design (CRD). All tests were conducted in triplicate. Data are reported as means \pm standard deviation (SD). Analysis of variance and significant differences among means were tested by one-way ANOVA using the COSTAT computer package (COHORT SOFTWARE, 1989). The least significant difference (LSD) at $\mathrm{P} \leq 0.05$ level was calculated. Correlation coefficients $\left(\mathrm{R}^{2}\right)$ from regression analysis between total phenolic or total flavonoid contents and antioxidant activities were also calculated.

\section{Results and discussion}

Calli of colocynth began to appear on stems, leaves and roots grown on MS media supplemented with different concentrations and combinations of growth regulators (2,4-D/KIN and BA/NAA) within one weak. The results presented in Table 2 shows that the stem explants grown on MD2 gave the highest frequency of callus formation (98.9 \%). Generally, among all 2,4-D and KIN combination treatments, the medium MD2 showed significant superiority in frequencies of callus formation for the three studied explants. These results are in accord with HEGAZY et al. (2010) who reported that high concentration of KIN more than 2,4-D in the MS-media had a positive effects on the callus induction (fresh and dry weight) in both stem and root explants of colocynth. On the other hand, DABAUZA et al. (1997) found that the highest frequency $(81.8 \%)$ of Citrullus colocynthis cotyledon explants derived calli was obtained on a medium containing $25 \mu \mathrm{M}$ 6-benzylaminopurine (6-BA).

Table 2. Callusing frequency of different explants derived from seedlings of colocynth cultured on MS media supplemented with different combinations of growth regulators.

\begin{tabular}{|c|c|c|c|c|}
\hline \multirow{3}{*}{$\begin{array}{l}\text { Growth } \\
\text { regulators } \\
\text { treatments }\end{array}$} & \multirow{3}{*}{ Media codes } & \multicolumn{3}{|c|}{ Callus formation frequency $(\%$, mean $\pm \mathrm{SD})$} \\
\hline & & \multicolumn{3}{|c|}{ Origin of callus (explants) } \\
\hline & & Stems & Leaves & Roots \\
\hline \multirow{4}{*}{ 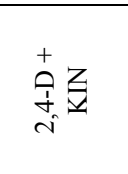 } & MD1 & $94.9 \pm 1.80^{\mathrm{e}}$ & $68.6 \pm 1.81^{\mathrm{b}}$ & $26.8 \pm 1.41^{\mathrm{a}}$ \\
\hline & MD2 & $98.9 \pm 1.10^{\mathrm{g}}$ & $86.4 \pm 1.38^{\mathrm{f}}$ & $61.1 \pm 0.95^{\mathrm{d}}$ \\
\hline & MD3 & $83.2 \pm 2.17^{\mathrm{b}}$ & $70.5 \pm 1.78^{\mathrm{c}}$ & $44.2 \pm 0.96^{\mathrm{b}}$ \\
\hline & MD4 & $98.8 \pm 1.20^{\mathrm{g}}$ & $47.8 \pm 0.82^{\mathrm{a}}$ & $45.2 \pm 1.29^{\mathrm{c}}$ \\
\hline \multirow{5}{*}{ 芯充 } & MB1 & $85.1 \pm 1.73^{c}$ & $85.0 \pm 1.30^{\mathrm{e}}$ & $68.6 \pm 1.58^{\mathrm{e}}$ \\
\hline & MB2 & $81.8 \pm 1.42^{\mathrm{a}}$ & $74.3 \pm 1.48^{\mathrm{d}}$ & $77.8 \pm 1.62^{\mathrm{f}}$ \\
\hline & MB3 & $97.9 \pm 1.38^{\mathrm{f}}$ & $98.2 \pm 1.17^{\mathrm{h}}$ & $91.7 \pm 1.80^{\mathrm{g}}$ \\
\hline & MB4 & $90.9 \pm 1.90^{\mathrm{d}}$ & $92.6 \pm 1.53^{\mathrm{g}}$ & $92.9 \pm 1.50^{\mathrm{h}}$ \\
\hline & $\mathrm{LSD} \leq 0.05$ & 0.699 & 0.324 & 0.281 \\
\hline
\end{tabular}

Data represents mean of 10 replicates per treatment in three repeated experiments. Data with different superscript letters in the same column were significantly different $(\mathrm{P} \leq 0.05)$. 
Fig. 1 and 2 show the total phenolics content in different colocynth callus cultures. One-way ANOVA analysis showed significant differences $(\mathrm{p} \leq 0.05)$ in total phenolics content among the eight studied media formulations. A wide range of total phenolics content was found in 2,4-D and KIN treatments as shown in Fig. 1. The high concentration of 2,4-D over KIN in MD3 media yielded the highest phenolics content (19.2 mg/100g d.w.) in the leaf derived calli. This content was higher than the content of phenolic compounds in stems, leaves and roots organs of seedlings $(3.32,17.1$ and $4.49 \mathrm{mg} / 100 \mathrm{~g} \mathrm{~d} . \mathrm{w}$.) which were used as controls.

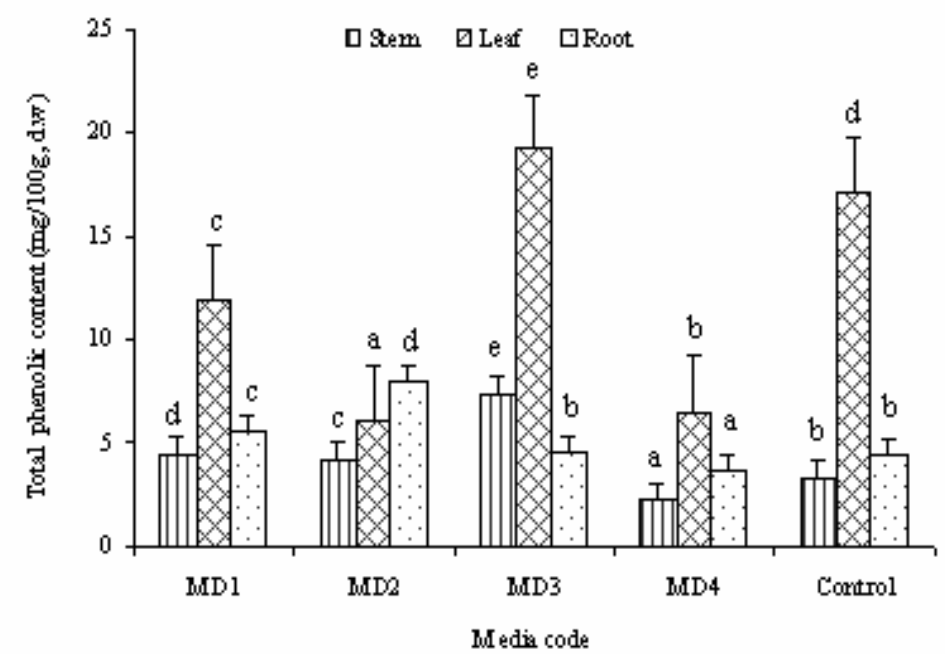

Fig. 1. Total phenolics content of colocynth callus cultures grown on MS media supplemented with different combinations and concentrations of 2,4-D and KIN. Data with different superscript letters in the same column were significantly different $(\mathrm{P} \leq 0.05)$. Bars on the columns represent the standard deviation.

Fig. 2 shows the total phenolics content in calli derived on BA and NAA containing media. Overall, the higher concentration of NAA over BA (MB2) gave the maximum amount of total phenolics $(7.54$ and $6.52 \mathrm{mg} / 100 \mathrm{~g} \mathrm{d.w}$.) in the stem and root derived calli respectively. Unlike, the lowest value of phenolics content $(2.71 \mathrm{mg} / 100 \mathrm{~g}$ d.w.) was detected in the leaf-derived calli cultured on medium MB3. The effect of plant growth regulators on biosynthesis of phenolic compounds were studied in hairy roots of Panax ginseng by JEONG et al. (2007). They found that addition of benzylaminopurine and kinetin to the culture media led to increasing the phenolic compound biosynthesis. In addition, NIKOLAEVA et al. (2009) reported that growing transgenic tea callus tissue (strain IFR ChS-2) on nutrient medium containing NAA at concentration of $2 \times 10^{-5} \mathrm{M}$ stimulated total soluble phenolics more than total phenolics which presented in intact plants.

The total flavonoid content showed significant $(\mathrm{P} \leq 0.05)$ differences among the explant types and the different combinations of growth regulators as shown in Fig. 3. Dealing with 2,4-D and KIN media treatments, MD3 gave the maximum values of total flavonoid content $(47.3 \mathrm{mg} / 100 \mathrm{~g} \mathrm{~d} . \mathrm{w}$.) in the stem derived calli. This content is higher than those contents $(11.8,46.4$ and $15.6 \mathrm{mg} / 100 \mathrm{~g} \mathrm{d.w.)}$ of in vitro raised 
seedlings stems, leaves and roots respectively, which were used as a control. It is clear that 2,4-D was the favorable enhancer of flavonoids accumulation in colocynth callus cultures. These results are in agreement with MATKOWSKI (2004), who reported that medium containing 2,4-D was found to be optimum for isoflavone accumulation in callus cultures of Pueraria lobata and Psoralea sp. Similarly, SHINDE et al. (2009) confirmed that the content of isoflavones in root and leaf-derived callus cultures of Psoralea corylifolia was higher on medium containing 2,4-D and IAA than in intact plant roots and leaves.

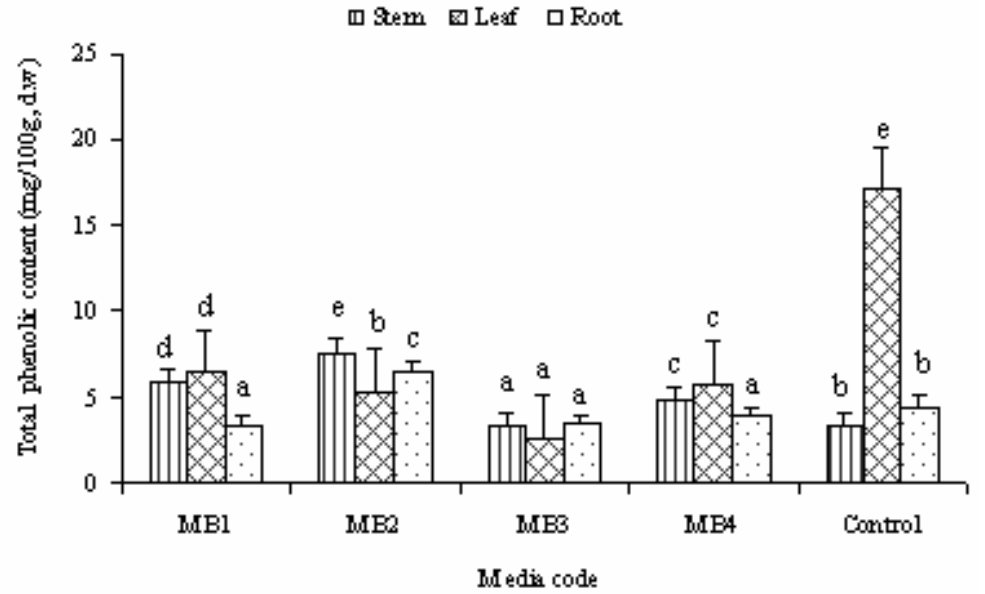

Fig. 2. Total phenolics content of colocynth callus cultures grown on MS media supplemented with different combinations of BA and NAA. Data with different superscript letters in the same column were significantly different $(\mathrm{P} \leq 0.05)$. Bars on the columns represent the standard deviation.

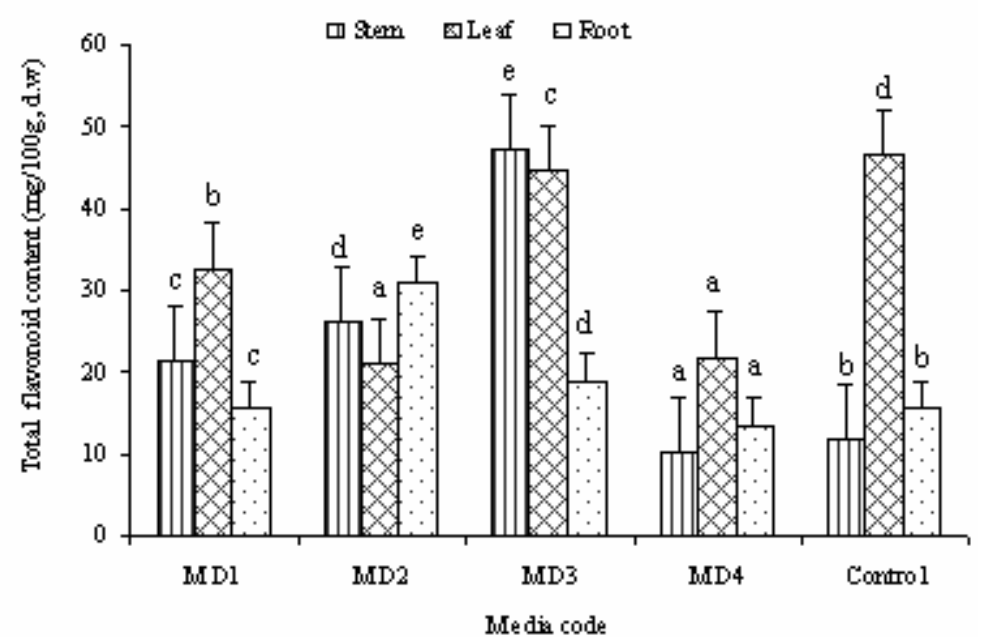

Fig. 3. Total flavonoid content of colocynth callus cultures grown on MS media supplemented with different combinations of 2,4-D and KIN. Data with different superscript letters in the same column were significantly different $(\mathrm{P} \leq 0.05)$. Bars on the columns represent the standard deviation. 
The effect of BA and NAA treatments on stimulation of total flavonoid content is presented in Fig. 4. The high concentration of BA over NAA (MB4 media) gave the highest flavonoid content $(34.0 \mathrm{mg} / 100 \mathrm{~g} \mathrm{d.w}$.) in the stem derived calli. However, this content is lower than the flavonoid content $(46.4 \mathrm{mg} / 100 \mathrm{~g} \mathrm{~d} . \mathrm{w}$.) detected in the leaves of the in vitro raised seedlings. The present results are in agreement with findings of AGARWAL and KAMAL (2007). The authors confirmed that the maximum flavonoid content was observed in 2 weeks old callus culture of Momordica charantia cultured on MS medium supplemented with NAA (2 mg/L) and BAP $(0.5 \mathrm{mg} / \mathrm{L})$.

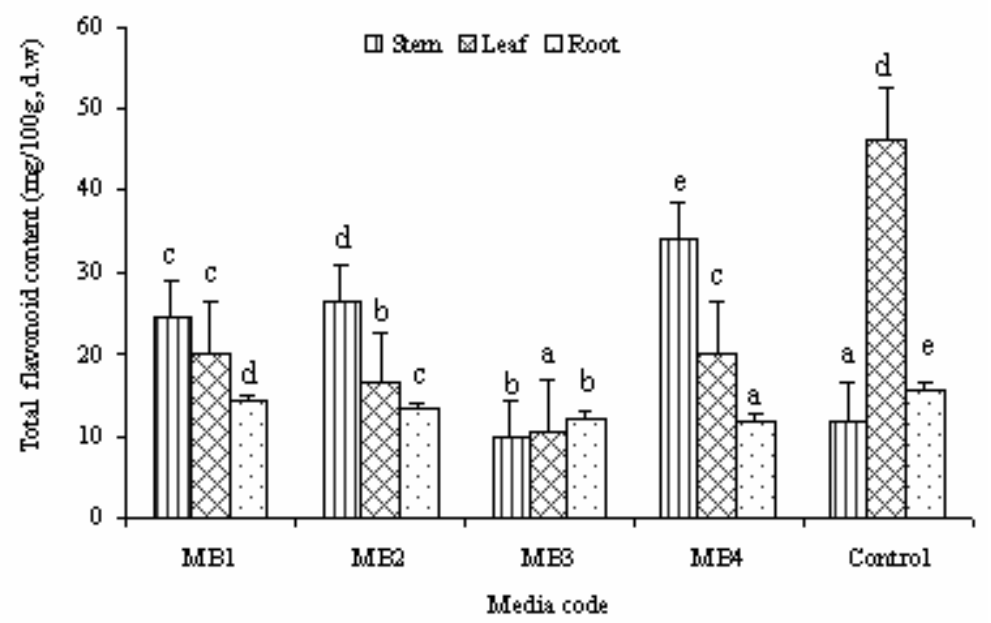

Fig. 4. Total flavonoid content of colocynth callus cultures grown on MS media supplemented with different combinations of BA and NAA. Data with different superscript letters in the same column were significantly different $(\mathrm{P} \leq 0.05)$. Bars on the columns represent the standard deviation.

It is well known that, the concentrations of phenolics content usually higher than the concentrations of flavonoid in most cases, but in this study we found an inverse trend. It can be explained by the fact that differences in the polarity of the extracting solvents could result in a wide variation in polyphenolic contents of the extract. So, the low content of phenolics in our extracts may be possibly due to the fact that extraction with methanol does not release bound phenolics from the callus cells. On the other side, the Folin-Ciocalteu method is a rapid and widely-used assay, to detect the total phenolic content but it is known that different phenolic compounds have different responses in the Folin-Ciocalteu method (KÄHKONEN et al., 1999). Moreover, different authors found a higher concentrations of flavonoid more than phenolics such as SULTANA et al. (2009) found a higher concentration of total flavonoids (1.68 $\mathrm{g} / 100 \mathrm{~g}$, d.w.) in absolute methanolic extract of Moringa oleifera root more than the total phenolics $(0.22 \mathrm{~g} / 100 \mathrm{~g}$, d.w.). Also, the aqueous extract of Momordica charantia yielded higher content of total flavonoid $(62 \mathrm{mg} / \mathrm{g}$, d.w.) than total phenolics $(51.6$ $\mathrm{mg} / \mathrm{g}$, d.w.) as reported by (WU and $\mathrm{Ng}, 2008$ ). The variation in the total flavonoid production may be attributed to the activation of key enzyme phenylalanine ammonialyase (PAL) which is involved in the flavonoid biosynthesis pathway (GUO et al., 
2007). The knowledge of biosynthetic pathway and mechanisms for stimulation of flavonoids production in callus culture remains unclear. Whether phytohormones induce different biosynthetic enzymes responsible for the biosynthesis of flavonoids is yet to be clarified.

The antioxidant activities of methanolic extracts of colocynth callus cultures and of the standard antioxidant BHT were determined using the DPPH method. This method is based on the reduction of alcoholic DPPH solution in the presence of a hydrogendonating antioxidant due to the formation of the non-radical form DPPH-H by the reaction (GÜLÇIN, 2006). The DPPH radical scavenging activity of methanolic extracts of colocynth callus cultures at concentration $500 \mu \mathrm{g} / \mathrm{mL}$ is presented in Table 3. The leaf-derived calli cultured on MD1 showed relatively higher radical scavenging activity $(85.3 \%)$ with $\mathrm{IC}_{50}$ value $(0.209 \mathrm{mg} / \mathrm{mL})$ as presented in Table 4 . This activity was higher than the activity of stem, leaf and root organs of seedling which were used as control $\left(51.6,80.9\right.$ and $27.9 \%$ ) with $\operatorname{IC}_{50}$ values $(0.485,0.241$ and $0.915 \mathrm{mg} / \mathrm{mL})$ respectively. The scavenging activity of BHT which was used as positive control showed higher activity $(87.5 \%)$ with $\mathrm{IC}_{50}$ value $(0.086 \mathrm{mg} / \mathrm{mL})$ than our methanolic extracts of colocynth callus cultures. These results are consistent with those of TADHANI et al. (2007) who found a relatively higher DPPH radical scavenging activity $(56.8 \%)$ with $\mathrm{IC}_{50}$ value $(0.528 \mathrm{mg} / \mathrm{mL})$ of extract of Stevia rebaudiana leafderived callus cultured on MS media supplemented with $2.0 \mathrm{mg} / \mathrm{L} \mathrm{NAA}$ and $0.3 \mathrm{mg} / \mathrm{L}$ BA than the activity $(33.2 \%)$ with $\mathrm{IC}_{50}$ value $(0.904 \mathrm{mg} / \mathrm{mL})$ of intact plant leaves.

Table 3. DPPH radical scavenging activity of colocynth callus cultures grown on MS media supplemented with different combinations of growth regulators.

\begin{tabular}{|c|c|c|c|c|}
\hline \multirow{3}{*}{$\begin{array}{l}\text { Growth } \\
\text { regulators } \\
\text { treatments }\end{array}$} & \multirow{3}{*}{ Media codes } & \multicolumn{3}{|c|}{ DPPH scavenging activity $(\%$, mean \pm SD $)$} \\
\hline & & \multicolumn{3}{|c|}{ Origin of callus (explants) } \\
\hline & & Stems & Leaves & Roots \\
\hline \multirow{4}{*}{ 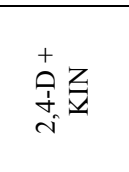 } & MD1 & $15.23 \pm 0.046^{\mathrm{g}}$ & $85.31 \pm 0.685^{\mathrm{i}}$ & $38.73 \pm 0.158^{\mathrm{h}}$ \\
\hline & MD2 & $11.62 \pm 0.016^{\mathrm{c}}$ & $56.32 \pm 0.213^{\mathrm{f}}$ & $27.55 \pm 0.110^{\mathrm{d}}$ \\
\hline & MD3 & $8.45 \pm 0.028^{\mathrm{a}}$ & $70.89 \pm 0.223^{\mathrm{g}}$ & $22.80 \pm 0.073^{\mathrm{c}}$ \\
\hline & MD4 & $10.02 \pm 0.016^{\mathrm{b}}$ & $23.01 \pm 0.084^{\mathrm{a}}$ & $28.17 \pm 0.081^{\mathrm{f}}$ \\
\hline \multirow{7}{*}{$\begin{array}{l}\mathbb{Z} \\
Z \\
+ \\
\mathbb{\infty}\end{array}$} & MB1 & $14.70 \pm 0.770^{\mathrm{f}}$ & $44.63 \pm 0.276^{\mathrm{c}}$ & $32.13 \pm 0.097^{\mathrm{g}}$ \\
\hline & MB2 & $13.83 \pm 0.012^{\mathrm{e}}$ & $46.78 \pm 0.014^{\mathrm{d}}$ & $19.56 \pm 0.035^{\mathrm{b}}$ \\
\hline & MB3 & $12.59 \pm 0.013^{\mathrm{d}}$ & $41.47 \pm 0.066^{\mathrm{b}}$ & $25.44 \pm 0.047^{\mathrm{a}}$ \\
\hline & MB4 & $16.60 \pm 0.073^{\mathrm{h}}$ & $49.32 \pm 0.110^{\mathrm{e}}$ & $59.42 \pm 0.204^{\mathrm{i}}$ \\
\hline & Control & $51.60 \pm 0.445^{\mathrm{i}}$ & $80.90 \pm 0.748^{\mathrm{h}}$ & $27.91 \pm 0.081^{\mathrm{e}}$ \\
\hline & $\mathrm{LSD} \leq 0.05$ & 0.442 & 0.705 & 0.299 \\
\hline & BHT $(150 \mu \mathrm{g} / \mathrm{mL})$ & & $87.50 \pm 0.099$ & \\
\hline
\end{tabular}

Note: Media formulations are presented in Table 1.

Each value is expressed as mean \pm standard deviation $(n=3)$. Data with different superscript letters in the same column were significantly different $(\mathrm{P} \leq 0.05)$.

In addition, GRZEGORCZYK et al. (2007) reported that the methanolic extracts $(50 \mu \mathrm{g} / \mathrm{mL})$ of Salvia officinalis shoot cultures grown on MS media supplemented with 
$0.1 \mathrm{mg} / \mathrm{L}$ IAA and $0.45 \mathrm{mg} / \mathrm{L}$ BAP possessed a high DPPH radical scavenging activity $(81.4 \%)$ comparable to that $(72.3 \%)$ of shoots from field collected plants. With respect to these results, it is possible to consider the callus cultures as a potential source of natural antioxidants. Although, which constituents of colocynth callus methanolic extracts, show the free radical scavenging action is still unclear. It is possible that the antioxidative properties of colocynth extracts are caused, at least in part, by the presence of polyphenols and flavonoids and other yet to be discovered antioxidant compounds.

Table 4. $\mathrm{IC}_{50}$ for inhibition of DPPH radical formation of colocynth callus cultures grown on MS media supplemented with different combinations of growth regulators

\begin{tabular}{|c|c|c|c|c|}
\hline \multirow{3}{*}{$\begin{array}{l}\text { Growth } \\
\text { regulators } \\
\text { treatments }\end{array}$} & \multirow{3}{*}{ Media codes } & \multicolumn{3}{|c|}{$\mathrm{IC}_{50}$ values (mg/mL, d.w.) of DPPH scavenging activity } \\
\hline & & \multicolumn{3}{|c|}{ origin of callus (explants) } \\
\hline & & Stems & Leaves & Roots \\
\hline \multirow{4}{*}{ 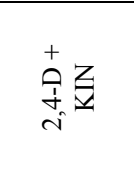 } & MD1 & 1.670 & 0.209 & 0.654 \\
\hline & MD2 & 2.190 & 0.449 & 0.919 \\
\hline & MD3 & 2.970 & 0.354 & 1.118 \\
\hline & MD4 & 2.500 & 1.090 & 0.898 \\
\hline \multirow{6}{*}{ 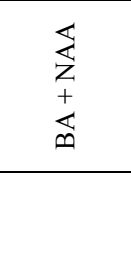 } & MB1 & 1.730 & 0.569 & 0.794 \\
\hline & MB2 & 1.860 & 0.540 & 1.325 \\
\hline & MB3 & 2.030 & 0.613 & 1.000 \\
\hline & MB4 & 1.520 & 0.511 & 0.428 \\
\hline & Control & 0.485 & 0.241 & 0.915 \\
\hline & BHT $(150 \mu \mathrm{g} / \mathrm{mL})$ & & 0.086 & \\
\hline
\end{tabular}

The presence of reductants such as antioxidant substances in samples causes the reduction of the $\mathrm{Fe}^{3+}$ ferricyanide complex to the ferrous form. The transformation of iron (III) to iron (II)-reducing activity in the colocynth callus methanolic extracts was expressed as $\mu \mathrm{g}$ ascorbic acid equivalent/g sample based on dry weight. The results showed statistically significant $(\mathrm{P} \leq 0.05)$ differences among the explant types and growth regulator treatments. Fig. 5 shows that the highest reducing power activity (22.3 $\mu \mathrm{g} / \mathrm{g}$ d.w.) was found in leaf-derived calli cultured on MD3 comparing to the activities $(3.28,12.9$ and $2.85 \mu \mathrm{g} / \mathrm{g}$ d.w.) of stems, leaves and roots of the in vitro seedlings which were used as controls, respectively.

Among the BA and NAA treatments, Fig. 6 indicated that high concentration of NAA in the medium (MB1) has notable effect on total reductive activity. It gave the highest activity $(7.52$ and $6.61 \mu \mathrm{g} / \mathrm{g}$ d.w.) in the callus cultures of stem and leaf explants respectively. However, these activities are lower than those of leaves of in vitro seedlings (12.9 $\mu \mathrm{g} / \mathrm{g}$ d.w.). In this concern, PARSAEIMEHR et al. (2010) reported that Ephedra strobilacea stem callus cultures grown on MS media supplemented with $1.5 \mathrm{mg} / \mathrm{L}$ NAA and $1 \mathrm{mg} / \mathrm{L}$ KIN gave ferric reducing antioxidant power $(0.28 \mathrm{mmol}$ quercetin $/ \mathrm{g})$. This value was lower than in intact plants $(1.61 \mathrm{mmol}$ quercetin $/ \mathrm{g})$. 


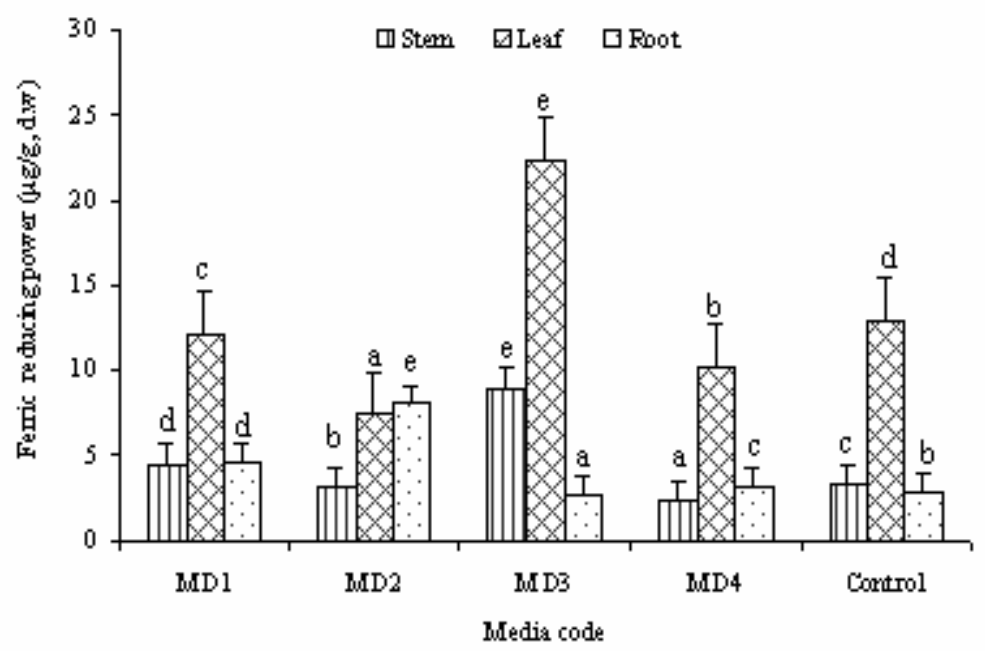

Fig. 5. Ferric reducing power of colocynth callus cultures grown on MS media supplemented with different combinations of 2,4-D and KIN. Data with different superscript letters in the same column were significantly different $(\mathrm{P} \leq 0.05)$. Bars on the columns represent the standard deviation.

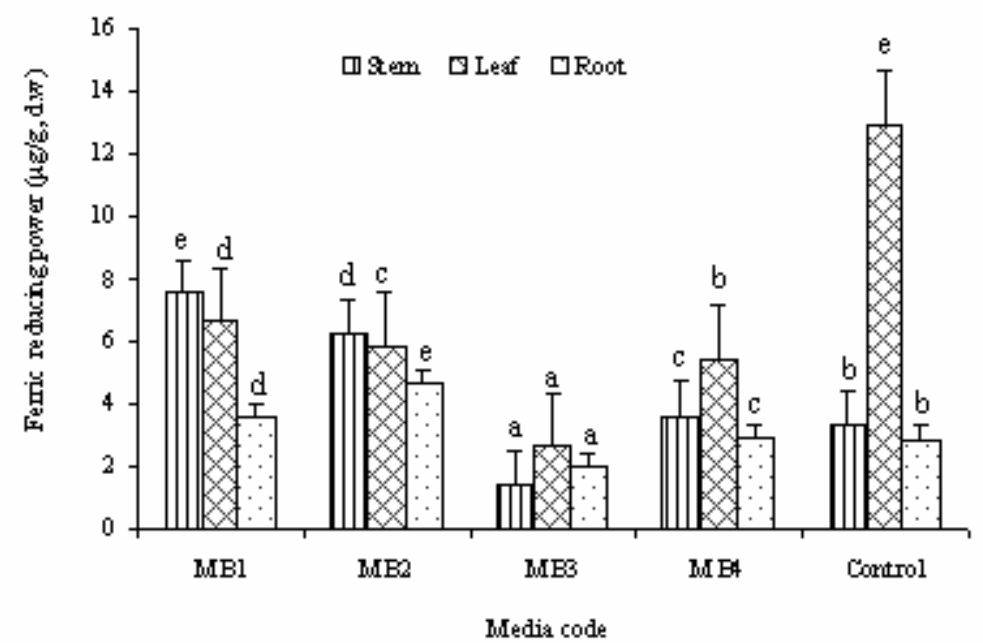

Fig 6. Ferric reducing power of colocynth callus cultures grown on MS media supplemented with different combinations of BA and NAA. Data with different superscript letters in the same column were significantly different $(\mathrm{P} \leq 0.05)$. Bars on the columns represent the standard deviation.

Hydrogen peroxide can cross membranes and may slowly oxidize a number of compounds. Thus, removing of hydrogen peroxide as well as superoxide anion is very important for protection of food systems (GÜLÇIN et al., 2007). Table 5 points out that $\mathrm{H}_{2} \mathrm{O}_{2}$ scavenging activity of colocynth callus methanolic extracts at concentration $150 \mu \mathrm{g} / \mathrm{mL}$ differed significantly $(\mathrm{P} \leq 0.05)$ among the different concentrations of 
growth regulators. Generally, high ratio of 2,4-D over KIN in MD1 exhibited remarkable scavenging activity on hydrogen peroxide, it gave the highest $\mathrm{H}_{2} \mathrm{O}_{2}$ scavenging activity $(61.4 \%)$ in leaf-derived calli with $\mathrm{IC}_{50}$ value $40.74 \mu \mathrm{g} / \mathrm{mL}$ as presented in Table 6 . This activity value was higher than the activity of the in vitro grown seedlings stems, leaves and roots organs (used as controls) which showed $\mathrm{H}_{2} \mathrm{O}_{2}$ scavenging activities of $26.2,27.3$ and $26.4 \%$ with $\mathrm{IC}_{50}$ values $95.4,91.7$ and 94.7 $\mu \mathrm{g} / \mathrm{mL}$, respectively. The $\mathrm{BHT}$ which was used as a positive control gave $\mathrm{H}_{2} \mathrm{O}_{2}$ scavenging activity of $90.5 \%$ with $\mathrm{IC}_{50}$ value $27.64 \mu \mathrm{g} / \mathrm{mL}$, this value was higher than in colocynth callus cultures. Moreover, high concentration of BA in MB4 media gave the highest hydrogen peroxide scavenging activity in the root derived calli $(51.8 \%)$.

Table 5. Hydrogen peroxide $\left(\mathrm{H}_{2} \mathrm{O}_{2}\right)$ scavenging activity of colocynth callus cultures grown on MS media supplemented with different combinations of growth regulators

\begin{tabular}{|c|c|c|c|c|}
\hline \multirow{3}{*}{$\begin{array}{l}\text { Growth } \\
\text { regulators } \\
\text { treatments }\end{array}$} & \multirow{3}{*}{ Media codes } & \multicolumn{3}{|c|}{$\mathrm{H}_{2} \mathrm{O}_{2}$ scavenging activity $(\%$, mean $\pm \mathrm{SD})$} \\
\hline & & \multicolumn{3}{|c|}{ Origin of callus (explants) } \\
\hline & & Stems & Leaves & Roots \\
\hline \multirow{4}{*}{$\begin{array}{l}+ \\
\stackrel{+}{+} z \\
\stackrel{+}{i},\end{array}$} & MD1 & $23.59 \pm 0.117^{\mathrm{b}}$ & $61.37 \pm 0.089^{\mathrm{g}}$ & $35.97 \pm 0.056^{\mathrm{h}}$ \\
\hline & MD2 & $24.26 \pm 0.139^{\mathrm{bc}}$ & $33.44 \pm 0.062^{\mathrm{d}}$ & $15.19 \pm 0.023^{\mathrm{a}}$ \\
\hline & MD3 & $21.36 \pm 0.110^{\mathrm{a}}$ & $39.22 \pm 0.407^{\mathrm{e}}$ & $17.47 \pm 0.027^{\mathrm{d}}$ \\
\hline & MD4 & $39.37 \pm 0.121^{\mathrm{e}}$ & $24.42 \pm 0.048^{\mathrm{a}}$ & $18.83 \pm 0.051^{\mathrm{e}}$ \\
\hline \multirow{7}{*}{ 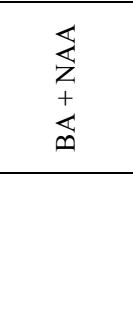 } & MB1 & $25.83 \pm 0.094^{\text {cd }}$ & $40.38 \pm 0.455^{\mathrm{f}}$ & $33.03 \pm 0.053^{g}$ \\
\hline & MB2 & $22.32 \pm 0.049^{\mathrm{ab}}$ & $30.00 \pm 0.070^{\mathrm{c}}$ & $16.72 \pm 0.026^{\mathrm{b}}$ \\
\hline & MB3 & $27.66 \pm 0.091^{\mathrm{d}}$ & $33.48 \pm 0.039^{d}$ & $16.75 \pm 0.053^{\mathrm{c}}$ \\
\hline & MB4 & $21.48 \pm 0.058^{\mathrm{ab}}$ & $38.44 \pm 0.062^{\mathrm{e}}$ & $51.77 \pm 0.079^{\mathrm{i}}$ \\
\hline & Control & $26.21 \pm 0.235^{\mathrm{d}}$ & $27.27 \pm 0.623^{\mathrm{b}}$ & $26.39 \pm 0.051^{\mathrm{f}}$ \\
\hline & $\mathrm{LSD} \leq 0.05$ & 1.572 & 1.088 & 0.022 \\
\hline & $\begin{array}{c}\text { BHT } \\
(50 \mu \mathrm{g} / \mathrm{mL})\end{array}$ & & $90.46 \pm 0.011$ & \\
\hline
\end{tabular}

Each value is expressed as mean \pm standard deviation $(\mathrm{n}=3)$.

Data with different superscript letters in the same column were significantly different $(\mathrm{P} \leq 0.05)$.

In this concern, RAKOTOARISON et al. (1997) found that both callus and cell suspension cultures of Crataegus monogyna showed high scavenging activities against $\mathrm{H}_{2} \mathrm{O}_{2}$. The decomposition of hydrogen peroxide into water may occur according to the presence and character of antioxidant compounds. Since antioxidant compounds present in the extract are good electron donors, they may accelerate the conversion of $\mathrm{H}_{2} \mathrm{O}_{2}$ into $\mathrm{H}_{2} \mathrm{O}$.

Phenolic and flavonoid compounds have been reported to be responsible for the antioxidant activities of medicinal plants and other botanical materials (MOHAMED et al., 2010). Table 7 shows that the total phenolic compounds gave a positive correlation $\left(\mathrm{R}^{2}=0.511\right.$ and $\left.\mathrm{R}^{2}=0.667\right)$ with DPPH radical scavenging activity and ferric reducing power respectively. These data could indicate that phenolic compounds in colocynth calli were the major contributors to DPPH radical scavenging activity and ferric reducing power. Polyphenolic compounds in extracts of colocynth 
callus cultures might play a role as electron and hydrogen donors. The antiradical activity of flavonoids and phenolics is principally based on the redox properties of their hydroxy groups and the structural relationships between different parts of their chemical structure (BURDA and OLESZEK, 2001). In this concern, SHINDE et al. (2009) indicated that the content of phenolics is partially correlated with DPPH radical scavenging $\left(\mathrm{R}^{2}=0.466\right)$ in callus cultures of Psoralea corylifolia.

Table 6. $\mathrm{IC}_{50}$ values of hydrogen peroxide $\left(\mathrm{H}_{2} \mathrm{O}_{2}\right)$ scavenging activity of colocynth callus cultures grown on MS media supplemented with different combinations of growth regulators.

\begin{tabular}{|c|c|c|c|c|}
\hline \multirow{3}{*}{$\begin{array}{l}\text { Growth } \\
\text { regulators } \\
\text { treatments }\end{array}$} & \multirow{3}{*}{ Media codes } & \multicolumn{3}{|c|}{$\mathrm{IC}_{50}$ values $\left(\mu \mathrm{g} / \mathrm{mL}\right.$, d.w.) of $\mathrm{H}_{2} \mathrm{O}_{2}$ scavenging activity } \\
\hline & & \multicolumn{3}{|c|}{ Origin of callus (explants) } \\
\hline & & Stems & Leaves & Roots \\
\hline \multirow{4}{*}{$\underset{\substack{+\dot{y}}}{+} Z$} & MD1 & 105.98 & 40.74 & 69.5 \\
\hline & MD2 & 103.05 & 74.76 & 164.58 \\
\hline & MD3 & 117.04 & 63.43 & 143.1 \\
\hline & MD4 & 63.50 & 102.38 & 132.77 \\
\hline \multirow{6}{*}{ 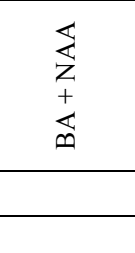 } & MB1 & 96.79 & 61.91 & 75.69 \\
\hline & MB2 & 112.01 & 83.33 & 149.52 \\
\hline & MB3 & 90.38 & 74.67 & 149.7 \\
\hline & MB4 & 116.39 & 65.04 & 48.29 \\
\hline & Control & 95.38 & 91.68 & 94.73 \\
\hline & BHT $(50 \mu \mathrm{g} / \mathrm{mL})$ & & 27.64 & \\
\hline
\end{tabular}

Table 7. Correlation analysis $\left(\mathrm{R}^{2}\right)^{*}$ between antioxidant activities and antioxidant content (total phenolics and total flavonoids).

\begin{tabular}{ccc}
\hline \multirow{2}{*}{ Antioxidant activities } & \multicolumn{2}{c}{ Antioxidant contents } \\
\cline { 2 - 3 } & Total phenolics & Total flavonoids \\
\hline DPPH radical scavenging activity & 0.511 & 0.048 \\
$\mathrm{H}_{2} \mathrm{O}_{2}$ scavenging activity & 0.017 & 0.026 \\
Ferric reducing power & 0.667 & 0.358 \\
\hline
\end{tabular}

${ }^{*}$ Correlation coefficient $\left(\mathrm{R}^{2}\right)$

However, the poor correlations of $\mathrm{H}_{2} \mathrm{O}_{2}$ scavenging activity $\left(\mathrm{R}^{2}=0.017\right)$ with the total phenolic compounds as well as the poor correlations of DPPH radical scavenging activity, $\mathrm{H}_{2} \mathrm{O}_{2}$ scavenging activity and ferric reducing power $\left(\mathrm{R}^{2}=0.048, \mathrm{R}^{2}=0.026\right.$ and $\mathrm{R}^{2}=0.358$ ) with total flavonoids respectively in this study suggested that flavonoid compounds in colocynth calli might be a weak scavenger of DPPH radical and $\mathrm{H}_{2} \mathrm{O}_{2}$ and they do not contribute to ferric reducing power.

In conclusion, the development of in vitro cell lines with high antioxidant capacities provides a possibility of generating uniform material cultured under conditions independent of environmental factors. The results of the present study concluded that MS media supplemented with 2,4-D and kinetin produced higher contents of total phenolics, total flavonoids and antioxidant activities more than MS 
media supplemented with BA and NAA in colocynth callus cultures. Stimulation of antioxidant activities in $C$. colocynthis will help to select callus culture type as a source of natural antioxidants and nutraceuticals to enhance health benefits. Moreover, more scientific work needs to be done regarding the characterization of effective antioxidant compounds contained in this plant species in order to further verify their antioxidant effects in in vitro conditions.

Acknowledgments: We are grateful to Dr. Mahmoud M. Saker, Professor of Plant Biotechnology, National Research Centre, where the practical part of tissue culture was carried out in his lab. We are also grateful to Dr. Ahmed K. Hegazy, Professor of Plant Ecology, Faculty of Science, Cairo University, for his critical reading of the manuscript.

\section{References}

ABOUZID, S.F., EL-BASSUONY, A.A., NASIB, A., KHAN, S., QURESHI, J., CHOUDHARY, M.I.: Withaferin A production by root cultures of Withania coagulans. Int. J. Appl. Res. Nat. Prod., 3, 2010, 23-27.

AGARWAL, M., KAMAL, R.: Studies on flavonoid production using in vitro culture of Momordica charantia L. Indian J. Biotechnol., 6, 2007, 277-279.

ALFERMANN, A.W., PETERSEN, M.: Natural products formation by plant cell biotechnology. Plant Cell Tissue Organ Cult., 43, 1995, 199-205.

BLOIS, M.S.: Antioxidant determinations by the use of a stable free radical. Nature, 181, 1958, 1199-1200.

BURDA, S., OLESZEK, W.: Antioxidant and antiradical activities of flavonoids. J. Agric. Food Chem., 49, 2001, 2774-2779.

COHORT SOFTWARE Inc.: Costat user manual version 3.03, Berkeley, CA, USA. 1989.

DABAUZA, M., BORDAS, M., SALVADOR, A.L., ROIG, A., MORENO, V.: Plant regeneration and Agrobacterium-mediated transformation of cotyledon explants of Citrullus colocynthis (L.) Schrad. Plant Cell Rep., 16, 1997, 888-892.

DELAZAR, A., GIBBONS, S., KOSARI, A.R., NAZEMYEH, H., MODARRESI, M., NAHAR, L., SARKER, S.D.: Flavone $C$-glycosides and cucurbitacin glycosides from Citrullus colocynthis. J. Fac. Pharm., Tehran University of Medicinal Sciences, 14, 2006, 109-114.

DORNENBURG, H., KNORR, D.: Challenges and opportunities for metabolite production from plant cell and tissue cultures. Food Technol., 51, 1997, 47- 54.

DUANGPORN, P., SIRIPONG, P.: Effect of auxin and cytokinin on phyllanthusol A production by callus cultures of Phyllanthus acidus Skeels. American-Eurasian J. Agric. Environ. Sci., 5, 2009, 258-263.

GRZEGORCZYK, I., MATKOWSKI, A., WYSOKINSKA, H.: Antioxidant activity of extracts from in vitro cultures of Salvia officinalis L. Food Chem., 104, 2007, 536-541.

GÜLÇIN, I.: Antioxidant and antiradical activities of L-carnitine. Life Sci., 78, 2006, 803-811.

GÜLÇIN, I., ELMASTAT, M., ABOUL-ENEIN, H.Y.: Determination of antioxidant and radical scavenging activity of Basil (Ocimum basilicum L. family Lamiaceae) assayed by different methodologies. Phytother. Res., 21, 2007, 354-361. 
GUO, B., LIU, Y.G., YAN, Q., LIU, C.Z.: Spectral composition of irradiation regulates the cell growth and flavonoids biosynthesis in callus cultures of Saussurea medusa Maxim. Plant Growth Regul., 52, 2007, 259-263.

HASSANANE, M.S., EL-FIKY, S., ABD EL-BASET, S.A.: A genotoxic study of the Citrullus colocynthis extract. Bull. Nat. Res. Centre (Egypt), 26, 2001, 223-235.

HEGAZY, A.K., MOHAMED, A. AMAL, ALI, S.I., SAKER, M.M.: Enhancement of callus induction and cucurbitacin content in Citrullus colocynthis L. (Schrad) using plant growth regulators. J. Alabama Acad. Sci., 81, 2010, 23-35.

JEONG, G.T., WOO, J.C., PARK, D.H.: Effect of plant growth regulators on growth and biosynthesis of phenolic compounds in genetically transformed hairy roots of Panax ginseng C. A. Meyer. Biotechnol. Bioproc. Eng., 12, 2007, 86-91.

KÄHKÖNEN, M. P., HOPIA, A. I., VUORELA, H. J., RAUHA, J. P., PIHLAJA, K., KUJALA, T. S., HEINONEN, M.: Antioxidant activity of plant extracts containing phenolic compounds. J. Agric. Food Chem., 47, 1999, 3954-3962.

KALIDASS, C., MOHAN, V.R., DANIEL, A.: Effect of auxin and cytokinin on vincristine production by callus cultures of Catharanthus roseus L. (apocynaceae). Trop. Subtrop. Agroecosystems, 12, 2010, 283-288.

KAUR, C., KAPOOR, H.C.: Antioxidant and total phenolic contents of some Asian vegetables, Int. J. Food Sci. Technol., 37, 2002, 153-161.

KIM, D.O., JEONG, S.W., LEE, C.Y.: Antioxidant capacity of phytochemicals from various cultivars of plums. Food Chem., 81, 2003, 321-326.

KONG, F., ZHANG, M., LIAO, S., YU, S., CHI, J., WEI, Z.: Antioxidant activity of polysaccharide-enriched fractions extracted from pulp tissue of Litchi Chinensis Sonn.. Molecules, 15, 2010, 2152-2165.

MANTELL, S.H., SMITH, H.: Cultural factors that influence secondary metabolites accumulations in plant cell and tissue cultures. In: S.H. Mantell, H. Smith (Eds.) Plant Biotechnology. Society for Experimental Biology, Seminar Series 18 Cambridge University Press, Cambridge, 1984, p. 75.

MATKOWSKI, A.: In vitro isoflavonoid production in callus from different organs of Pueraria lobata (Wild.) Ohwi. J. Plant Physiol., 161, 2004, 343-346.

MATKOWSKI, A., PIOTROWSKA, M.: Antioxidant and free radical scavenging activities of some medicinal plants from the Lamiaceae. Fitoterapia, 77, 2006, 346353.

MOHAMED, A. AMAL, KHALIL, A.A., EL-BELTAGI, H.E.S.: Antioxidant and antimicrobial properties of kaff maryam (Anastatica hierochuntica) and doum palm (Hyphaene thebaica). Grasas Aceites, 61, 2010, 67-75.

MURASHIGE, T., SKOOG, F.: A revised medium for rapid growth and bio- assay with tobacco tissue cultures. Physiol. Plant., 15, 1962, 473-497.

NIKOLAEVA, T.N., ZAGOSKINA, N.V., ZAPROMETOV, M.N.: Production of phenolic compounds in callus cultures of tea plant under the effect of 2,4-D and NAA Russ. J. Plant Physiol., 56, 2009, 45-49.

PARSAEIMEHR, A., SARGSYAN, E., JAVIDNIA, K.: A comparative study of the antibacterial, antifungal and antioxidant activity and total content of phenolic compounds of cell cultures and wild plants of three endemic species of Ephedra. Molecules, 15, 2010, 1668-1678. 
RAKOTOARISON, D.A., GRESSIER, B., TROTIN, F., BRUNET, C., DINE, T., LUYCKX, M.: Antioxidant activities of polyphenolic extracts from flowers, in vitro callus and cell suspension cultures of Crataegus monogyna. Pharmazie, 52, 1997, 60-64.

RAO, S.R., RAVISHANKAR, G.A.: Plant cell cultures: chemical factories of secondary metabolites. Biotechnol. Adv., 20, 2002, 101-153.

SEGER, C., STURM, S., MAIR, M.E., ELLMERER, E.P., STUPPNER, H.: ${ }^{1} \mathrm{H}$ and ${ }^{13} \mathrm{C}$ NMR signal assignment of cucurbitacin derivatives from Citrullus colocynthis (L.) Schrader and Ecballium elaterium L. (Cucurbitaceae). Magn. Reson. Chem., 43, 2005, 489-491.

SEITZ, H.U., HINDERER, W.: Anthocyanins. In: F. CONSTABEL, I. VASIL (Eds.) Cell culture and somatic cell genetics of plants, Academic Press, San Diego, vol. 5, 1988, 49-76.

SHINDE, A., MALPATHAK, N.N., FULZELE, D.P.: Determination of isoflavones content and antioxidant activity in Psoralea corylifolia L. callus cultures. Food Chem., 118, 2009, 128-132.

SHON, M.Y., LEEB, J., CHOID, J.H., CHOIA, S.Y., NAMC, S.H., SEOD, K.I., LEEE, S.W., SUNGA, N.J., PARKD, S.K.: Antioxidant and free radical scavenging activity of methanol extract of chungkukjang. J. Food Compos. Anal., 20, 2007, 113-118.

SULTANA, B., ANWAR, F., ASHRAF, M. : Effect of extraction solvent/technique on the antioxidant activity of selected medicinal plant extracts. Molecules, 14, 2009, 2167-2180.

TADHANI, M.B., PATEL, V.H., SUBHASH, R.: In vitro antioxidant activities of Stevia rebaudiana leaves and callus. J. Food Compos. Anal., 20, 2007, 323- 329.

WU, S. J., NG, L. T.: Antioxidant and free radical scavenging activities of wild bitter melon (Momordica charantia Linn. var. abbreviata Ser.) in Taiwan. LWT - Food Sci. Tech., 41, 2008, 323-330.

ZHAO, H., FAN, W., DONG, J., LU, J., CHEN, J., SHAN, L., LIN, Y., KONG, W.: Evaluation of antioxidant activities and total phenolic contents of typical malting barley varieties. Food Chem., 107, 2008, 296-304.

ZIYYAT, A., LEGSSYUR, A., MEKHFI, H., DASSOULI, A., SEHRROUCHNI, M., BENJELLOUN, W.: Phytotherapy of hypertension and diabetes in oriental Morocco. J. Ethnopharmacol., 58, 1997, 45-54. 